\title{
TATA KELOLA BUMDES: PEMUDA SEBAGAI PENGGERAK BUMDES DALAM MENDORONG PEMBERDAYAAN MASYARAKAT PEDESAAN
}

\author{
GOVERNANCE BUMDES: YOUTH AS A BUMDES DRIVER IN \\ PROMOTING RURAL COMMUNITY EMPOWERMENT
}

\author{
Zulfiani \\ Universitas Islam Negeri Makassar \\ E-mail: zulfianimasud21@gmail.com \\ Khairina Almirah Rivai \\ Pascasarjana Unhas
}

Naskah diterima tanggal 29 Desember 2020. Naskah direvisi tanggal 30 Desember 2020. Naskah disetujui tanggal 31 Desember 2020

\begin{abstract}
Abstrak
Penelitian ini akan melihat keterlibatan pemuda sebagai penggerak BUMDes yang berupaya mengentaskan kemiskinan masyarakat pedesaan. Dengan pertanyaan penelitian, bagaimana bentuk keterlibatan pemuda dalam tata kelola Bumdes di desa Pitue. Pertanyaan ini di gunakan untuk melihat kasus BUMDes Mattuju di desa Pitue, Kabupaten Pangkep Sulawesi Selatan. BUMDes di desa Pitue sebagai salah satu BUMDes di Sulawesi Selatan yang di kenal sebagai $B U M D e s$ yang cukup berhasil dalam mendorong keterlibatan dan pemberdayaan masyarakat, yang dampak dominonya pada pendapatan masyarakat. Penelitian menggunakan metode deskriptif kualitatif, dengan Teknik pengumpulan data menggunakan observasi langsung dan wawancara mendalam. Hasil penelitian menunjukan, jika keberhasilan BUMDes desa Pitue mendorong keterlibatan dan pemberdayaan masyarakat tidak terlepas dari keterlibatan pemuda sebagai aktor kunci. Pemuda sebagai katalisator yang punya andil sangat besar dalam memajukan BUMDes di desa Pitue.
\end{abstract}

Kata Kunci: BUMDes, Partisipasi, Pemberdayaan, Dana Desa, Pemuda

\begin{abstract}
This research will look at how youth involvement as the activator of BUMDes which seeks to alleviate poverty in rural communities. This question is used to see the case of BUMDes Mattuju in Pitue village, Pangkep Regency, South Sulawesi. BUMDes in Pitue village is one of the BUMDes in South Sulawesi known as BUMDes which is quite successful in encouraging community involvement and empowerment, which has a dominant impact on community income. The results showed, if the success of the Pitue Village BUMDes in encouraging community involvement and empowerment could not be separated from the involvement of youth as key actors. Youth as catalysts have a very big role in advancing BUMDes in Pitue village. The study used a qualitative descriptive method, with data collection techniques using direct observation and in-depth interviews.
\end{abstract}

Keywords: BUMDes, Participation, Empowerment, Village Funds, Youth

\section{PENDAHULUAN}

Kemiskinan pedesaan masih menjadi persoalan utama di Indonesia (Hermawan,
2015; Jati, 2014; Nasfi, 2020; Sumarti, 2007; Tohani, 2011). Kemiskinan pedesaan menjadi masalah serius yang tidak hanya menyita para akademisi tetapi 
juga praktisi pemerintahan, termasuk yang melanda Pemerintah Kabupaten Pangkajene dan Kepulauan. BPS mencatat, angka kemiskinan di Kabupaten Pangkep dan Kepulauan menyentuh angka 14,05 \% dari total penduduk di Kabupaten Pangkep dan Kepulauan. Angka ini menjadikan Kabupaten Pangkep dan Kepulauan sebagai daerah kedua dengan tingkat kemiskinan tertinggi di Sulawesi Selatan setelah daerah Kabupaten Jeneponto.

\begin{tabular}{|c|l|c|}
\hline No & Kabupaten/Kota & $\begin{array}{c}\text { Persentase } \\
\text { Penduduk } \\
\text { Miskin }\end{array}$ \\
\hline 1 & Jeneponto & 14,88 \\
\hline 2 & Pangkep & 14,06 \\
\hline 3 & Luwu Utara & 13,60 \\
\hline 4 & Selayar & 12,83 \\
\hline 5 & Luwu & 12,78 \\
\hline
\end{tabular}

Sumber: BPS, 2019

Tabel 1 Persentase Penduduk Miskin Kab/ Kota Lima Tertinggi di Sulawesi Selatan, 2019

Di Kabupaten Pangkajene dan Kepulauan masalah mengenai kemiskinan sudah menjadi prioritas pemerintah daerah (Hasbi, M. Tang, 2019; Noveria \& Malamassam, 2015; Syam, n.d.). Berbagai upaya telah dilakukan dalam memerangi kemiskinan di pedesaaan di Pangkep. Salah satu yang paling menyita perhatian belakangan ini adalah upaya pengentasan kemiskinan melalui intervensi dana desa, yang salah satu wujudnya berupa BUMDES (Badan usaha milik desa). $B U M D e s$ dipercaya menjadi solusi di tengah benang kusut masalah kemiskinan pedesaan. Kehadiran BUMDes di harapkan dapat mengurasi benang kusut yang ada, setidaknya mengurangi angka kemiskinan di desa. Seiring dengan itu, pemerintah Pusat melalui skema dana desa telah menggelontorkan anggaran yang cukup besar untuk setiap tahunnya. Terhitung sejak tahun 2017 hingga 2019 alokasi untuk dana desa di Indonesia mengalami peningkatan yang cukup signifikan. Dari Rp 128.192.106.100 di tahun anggaran 2017 menjadi Rp 151.051.618.00 di tahun 2019 .

\begin{tabular}{|l|l|}
\hline Tahun & Dana Desa \\
\hline 2017 & Rp. 128.192 .106 .100 \\
\hline 2018 & Rp. 139.918 .865 .000 \\
\hline 2019 & Rp. 151.051 .618 .000 \\
\hline
\end{tabular}

Sumber: Dinas Pemberdayaan masyarakat dan desa Kab. Pangkajene dan Kepulauan. Data sekunder,diolah

Tabel. 2. Dana Desa di Kabupaten Pangkajene dan Kepulauan 2017-2019

Keseriusan pemerintah dalam mengentaskan masalah kemiskinan melalui program $B U M D e s$ juga nampak pada penciptaan $B U M D e s$ yang telah meningkat sangat tinggi. Sejak pertama kali di rilis di tahun 2014, dana desa telah menciptakan sebanyak 1022 BUMDes, tidak cukup lima tahun tepatnya di tahun 2018 BUMDes di Indonesia telah meningkat hingga $300 \%$ menjadi 45.549 unit BUMDes. Kenaikan ini cukup fantastis, sekaligus menjadi catatan penting bahwa sejak 2014 skema dana desa dan pengentasan kemiskinan masayarakat pedesaan melalui skema Bumdes menjadi fokus perhatian pemerintah. Kemiskinan, dan BUMDes yang saling terkait erat.

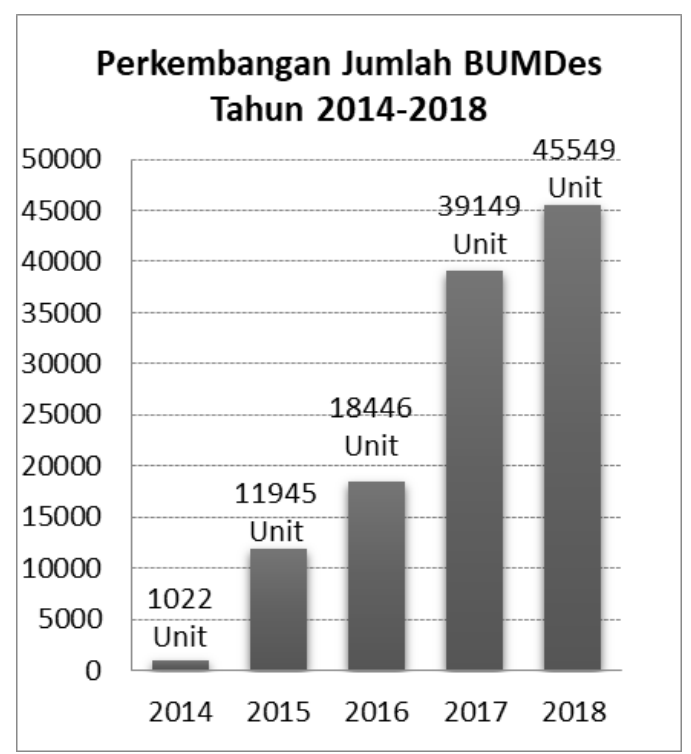


Sumber: Kemendes PDTT, 2019. Data sekunder,diolah

Kendati demikian, kasus di Desa Pitue Kabupaten Pangkep menjadi kasus yang menarik untuk di lihat. Pasalnya, meskipun secara kuantitatif angka kemiskinan belum beranjak secara signifikan, namun keterlibatan pemuda dalam mendorong kegiatan BUMDes telah berbuah pada pemberdayaan masyarakat pedesaan. Keterlibatan pemuda pada BUMDes masih sangat minim di bicarakan oleh para sarjana. Melalui sentuhan pemuda, BUMDes di desa Pitue menjadi lebih aktif dengan kegiatankegiatan pemberdayaan yang melibatkan masyarakat secara luas.

Beberapa studi yang ada tentang BUMDes di Indonesia memang sejauh ini belum menempatkan pemuda sebagai katalisator yang penting (Laru \& Suprojo, 2019; Perdianto et al., 2020; Suryana et al., 2015). Pemuda masih tersisih dari perhatian para sarjana. Pendekatanpendekatan yang selama ini digunakan dalam melihat tata kelola $B U M D e s$ di desa lebih banyak bertumpu pada pendekatanpendekatan tradisional yang sifatnya sangat klasik. Beberapa diantaranya, hanya berkutat pada persoalan kekeluarga dan kekerabatan. Hasilnya, beberapa BUMDes hanya berakhir sebagai koperasi simpan pinjam atau jika tidak, menjadi lembaga dana bergulir.

Kasus di desa Pitue menyajikan abstraksi kasus yang menarik di lihat. Sebab, kehadiran BUMDes di satu sisi telah di topang oleh alokasi anggaran yang cukup memadai. Melalui skema dana desa yang di perkuat dalam regulasi UU NO. 6 Tahun 2014, sementara pada sisi yang lain, saat ini Indonesia sedang menuju ke masa ke emasan, bonus demografi (Falikhah, 2017; Maryati, 2015; Noor, 2015; Umar, 2020). Situasi yang mengantarkan Indonesia pada kondisi surplus usia produktif (usia muda). Keterlibatan pemuda pada $B U M D e s$, seperti yang berlangsung di Desa Pitue menjadi satu kasus yang dapat di tularkan pada desa-desa lain di Indonesia.

\section{TINJAUAN PUSTAKA}

\section{Kemiskinan, Pemberdayaan dan BUMDes di Indonesia}

Berbagai

studi

pemberdayaan,

BUMDes

tentang

pemberantasan kemiskinan di pedesaan yang saling terkait telah berlangsung di Indonesia (Hayyuna et al., 2014; Sayuti, 2011; Yuni et al., 2013). Studi ini telah banyak di bicarakan, menghasilkan dialektika yang sangat produktif antara para sarjana. Secara garis besar, ada dua kesimpulan besar yang di hasilkan oleh para sarjana dalam melihat tautan antara kemiskinan pedesaan, pemberadayaan dan kehadiran BUMDes. Sebagian sarjana membangun kesimpulan jika keberadaan BUMDes saat ini belum cukup efektif mengatasi dua masalah mendasar yang berlangsung di pedesaan yaitu masalah kemsikinan dan rendahnya keikutsertaan masyarakat dalam kegiatan pemberdayaan (Prasetyo, 2016; Ridlwan, 2015; Sudirno et al., 2020). Sementara yang lain melihat dengan kesimpulan yang berbeda. Sebagian lagi menganggap jika $B U M D e s$ yang di rilis bersamaan dengan UU NO 6 Tahun 2014 tentang berkontribusi sangat besar dalam mengatasi masalah kemiskinan dan pemberdayaan yang berlangsung di pedesaan di Indonesia (Faedlulloh, 2018; Laru \& Suprojo, 2019; Rahmatika et al., 2019).

Beberapa diantara sarjana yang melihat jika tautana antara kemiskinan, pemberdayaan dan kehadiran BUMDes punya andil cukup besar adalah Sudirno, argumen yang di bangun oleh Sudirno, mengatakan bahwa BUMDes cukup sukses dalam mengantarkan masyarakat pedesaan keluar pada masalah kemiskinan. Meskipun apa yang di lihat oleh Sudirno hanya terbatas pada satu kasus di salah satu desa di Panjalin Kidul setidaknya karakteristik kasus ini bagi Sudirno hampir menyerupai karakteristik desa di Indonesia pada umumnya. Atas dasar ini, tidak sulit bagi Sudirno untuk membangun argument jika kehadiran BUMDes di Indonesia cukup sukses memerangi kemiskinan 
(Sudirno et al., 2020).

Begitupun dengan gagasan yang disampaikan oleh Prasetyo juga membenarkan pendapat bahwa kehadiran BUMDes di Indonesia telah mengambil peran yang sangat penting. Pasalnya, kehadiran BUMDes mampu menopang perekonomian masyarakat desa, terutama untuk mendorong kegiatan ekonomi yang berbasis lokal. Bagi Prasetyo BUMDes sebagai wadah yang bukan hanya memberikan wadah bagi pengembangan ekonomi dan potensi lokal yang ada di desa (Prasetyo, 2016). Tetapi, lebih dari itu oleh Prasetyo kehadiran BUMDes menjadi katalisator yang ikut mengikis kemiskinan di pedesaan sekaligus ikut mendorong keterlibatan masyarakat dalam kegiatan di desa. Kendati, BUMDes sejauh ini menurut Prasetyo masih perlu mendapat perhatian khususnya untuk aspek partisipasi masyarakat.

Selain itu, Ridlwan memiliki pandangan yang sedikit berbeda dalam melihat tautan antara kemiskinan pedesaaan, pemberdayaan dan BUMDes di Indonesia. Kendati berakhir dengan kesimpulan yang sama bahwa BUMDes cukup sukses mengikis kemiskinan di Indonesia (Ridlwan, 2015). Hanya saja Ridlwan, menitikberatkan pada aspek kelembagaan dan tata kelola yang profesional. Bagi Ridlwan keberhasilan BUMDes dalam mengetaskan masalah kemiskinan tidak lepas dari adanya profesionalisme. Faktor profesionalisme menjadi faktor kunci yang harus di miliki oleh $B U M D e s$ di Indonesia atau jika tidak, maka kehadiran BUMDes justru hanya akan menjadi beban bagi pemerintah di desa. Prasyarat kelembagaan dan tata kelola yang profesional menjadi kata kunci yang harus ada dimiliki oleh BUMDes. Prasyarat ini sekaligus menjadi penentu arah dan masa depan BUMDes.

Sementara itu, para sarjana yang melihat pesimis kehadiran BUMDes dengan masalah kemsikinan dan pemberdayaan di pedesaan di Indonesia, salah satunya di populerkan oleh Faedlulloh. Bagi Faedlulloh kehadiran $B U M D e s$ di desa belum cukup signifikan mengatasi masalah kemiskinan
(Faedlulloh, 2018). Penyebabnya, masalah skema organisasi partisipatoris yang masih sangat minim di miliki oleh pengelola BUMDes. Dampaknya, kreatifitas yang muncul di BUMDes sangat kecil. Implikasi dominonya, BUMDes hanya berkutat pada persoalan simpan pinjam dan kegiatan koperasi yang incomenya sangat kecil terhadap pendapatan asli desa.

Hal senada di sampaikan oleh Laru \& Suprojo bahwa kehadiran BUMDes di desa perlu mendapatkan apresiasi. Bagi Laru \& Suprojo ini adalah satu terobosan baru yang ada di desa. Tetapi, menyikapi $B U M D e s$ di desa juga tidak boleh terlalu berlebihan (Laru \& Suprojo, 2019). Faktanya, menurut Laru \& Suprojo catatan penelitian yang dia peroleh menunjukan jika BUMDes sejauh ini belum menunjukan korelasi yang sebanding dengan kemiskinan yang ada di desa . Bagi Laru \& Suprojo, sejauh ini penyebabnya karena kapasitas pengelolaan BUMDes yang di kerjakan belum dilakukan secara professional. BUMDes di beberapa desa penelitian yang di lakukan oleh Laru \& Suprojo terkesan hanya menjadi tempat menampung kerabat. Nilai kekerabatan dan kekeluarga lebih dominan ketimbang dengan nilai profesionalitas. Implikasinya, pada kinerja BUMDes secara keseluruhan yang masih belum optimal dalam memerangi kemiskinan yang ada di pedesaan.

Begitupun dengan Rahmatika membangunan gagasan yang sangat pesimis melihat tautan antara kemiskinan pedesaan dengan pemberdayaan dan BUMDes (Rahmatika et al., 2019). Menurut Rahmatika BUMDes menjadi sesuatu yang sangat berguna bagi masyarakat dan komunitas ekonomi lokal di desa. Namun, itu perlu dalam jangka waktu yang panjang. Pemeirntah mesti menyiapkan banyak instrument untuk mencapai titik itu. Salah satu instrument yang penting bagi Rahmatika adalah sumber daya manusia yang mumpuni, infrastruktur organisasi desa yang menunjang serta pemetaan potensi desa yang akurat. Sayangnya, bagi instrument ini belum menopang kehadiran BUMDes untuk saat ini. Sehingga bagi Rahmatika 
BUMDes belum bisa berkontribusi besar terhadap penurunan angka kemiskinan di desa serta belum cukup efektif menjadi wadah bagi pemberdayaan masyarakat pedesaan.

\section{Tata Kelola BUMDes :Pemuda Sebagai Aktor Penggerak}

Sejak di rilis pertama kali di tahun 2014 BUMDes menjadi primadona di desa yang dipercaya dapat mengentaskan berbagai masalah klasik pedesaan, salah satunya masalah kemiskinan (Alkaff, 2016; Hayyuna et al., 2014; Salam, 2018; Sayuti, 2011; Yuni et al., 2013). Kehadiran BUMDes mengobati rasa haus masyarakat desa yang selama ini merindukan otonomi desa dalam wujud pengelolaan sumber daya lokal secara mandiri. Melalui BUMDes, segenap komponen masyarakat di desa bisa berkreasi mengembangkan segala sumber daya dan potensi yang dimiliki demi untuk memajukan desa dan meningkatkan taraf pendapatan masyarakat desa. Tujuannya, tentu saja mengharapkan tingkat kemiskinan di desa dapat berkurang secara perlahan-lahan.

Seiring dengan perkembangan BUMDes di Indonesia, berbagai eksperimen di lakukan oleh masyarakat. Inisiatif masyarakat terus bermunculan dari bawah, mereka mencoba mencari formula yang tepat tentang tata kelola BUMDes yang sesuai dengan karakteristik desa yang ada. Rumitnya, karena karakteristik desa di Indonesia cukup beragam. Satu desa dengan desa yang lainnya bahkan dalam jarak yang sangat dekat bisa saja muncul dengan karakter yang berbeda. Hal ini akan berimplikasi pada corak dan tata kelola BUMDes.

Di Indonesia sendiri, secara regulasi belum ada aturan baku yang secara pasti mengatur mengenai tata kelola BUMDes. Seperti semangat UU No. 6 Tahun 2014, pemerintah dan perangkat pemerintah di desa di beri kewenangan penuh untuk berkreasi menentukan sendiri corak dan karakteristik BUMDes yang tepat sesuai dengan desa yang ada. Berbagai penelitian di berbagai tempat di desa di Indonesia setidaknya memberikan abstraksi kasus demi kasus tentang tata kelola BUMDes.
Sebagai contohnya, di Kabupaten Kerinci tata kelola BUMDes yang berhasil dalam hal mendorong pemberdayaan masyarakat desa khususnya keterlibatan peran Pemuda (Perdianto et al., 2020). Keberhasilan ini karena tata kelola BUMDes yang bertumpu pada aktor utama penggerak BUMDes yaitu aparat pemerintah desa. Keterlibatan aparat pemerintah desa dan peran pemuda sangat efektif dalam menggerakan BUMDes dan mendorong pemberdayaan masyarakat.

Namun, kasus ini belum sepenuhnya bisa di jadikan sebagai abstraksi kasus yang berhasil secara general. Pasalnya, di beberapa tempat lain di Indonesia justru keterlibatan aparat pemerintah desa dan keterlibatn pemuda yang terlalu berlebih menjadi penghambat berkembangnya BUMDes. BUMDes menjadi sangat tergantung. Implikasinya, kreatifitas $B U M D e s$ menjadi sangat minim. Kasus ini setidkanya diabadikan oleh Firdaus, yang kemudian menganggap bahwa keterlibatan aparat pemerintah yang terlalu berlebih tidak sehat untuk perkembangan $B U M D e s$ di desa (Firdaus, 2018).

Tata kelola BUMDes yang lain dapat di lihat dari hasil kerja yang dilakukan oleh Rahmatika penelitian yang dilakukan oleh Rahmatika mencoba melihat tata kelola BUMDes dengan mendorong Metode Tetraprenuer dan kemitraan (Rahmatika et al., 2019). Bagi, ini adalah salah satu tata kelola yang cukup berhasil dalam memajukan BUMDes. Dengan metode Tetraprenuer dan kemitraan aset BUMDes dapat bertambah, tidak stagnan dengan hanya mengandalkan suntikan dana dari dana desa. Metode Tetraprenuer dan kemitraan membuat BUMDes sedikit demi sedikit dapat mandiri secara keuangan. Mandiri dalam hal, tidak lagi mengandalkan sumder dana desa sebagai sumber utama kegiatan $B U M D e s$.

Berbeda dengan Rozaki ) yang mencoba mengembangkan tata kelola BUMDes dengan mendorong penggunaan teknologi. Bagi Rozaki penggunaan teknologi sebagai upaya tata kelola BUMDes dalam wujud Integrated information System (Abdur Rozaki \& Siti Rohaya, 2019). Integrasi informasi system 
akan mempermudah pengembangan BUMDes. Sayangnya, cara ini di sebagian desa di Indonesia belum relevan untuk di lakukan. Salah satu penyebabnya minimnya dukungan dan infrastruktur internet. Kalaupun akses internet tersedia, kendala klasik yang hadapai oleh sebagian desa di Indonesia adalah ketesediaan tenaga professional yang masih minim.

Dari berbagai pendekatan yang ada, setidaknya bisa di lihat jika upaya menghadirkan $B U M D e s$ sebagai salah satu solusi mengentaskan masalah kemiskinan dan mengembangkan pemberdayaan masyarakat pedesaan terus mengalami pasang-surut. Belum ada konsep baku yang dapat di jadikan sebagai patokan dalam hal tata kelola BUMDes di Indonesia. Namun dari berbagai praktek yang telah dilakukan oleh pemerintah desa yang di abadikan oleh para sarjana, setidaknya dapat di tarik konseptualisasi model tata kelola BUMDes yang pada umumnya di kembangkan di Indonesia. Dengan mengacu pada tiga aspek, aktor pelaksana, metode, penerapan teknologi dan sasaran atau output.

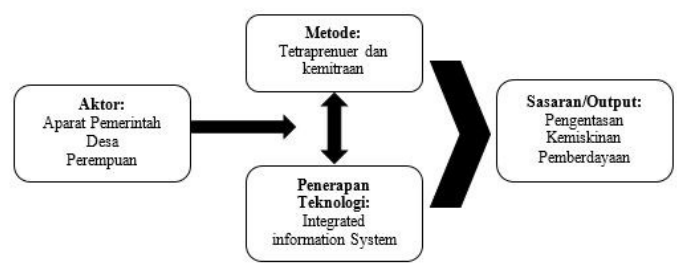

Sumber: Dikembangkan dari beberapa sumber artikel, diolah

\section{Bagan 1. Skema Tata Kelola BUMDes}

Skema ini yang berupaya di duplikasi oleh penelitian ini dengan mengembangkan karakteristik aktor. Namun, aktor disni tidak mengaju kepada aktor aparat pemerintah dan perempuan. Penelitian ini menawarkan aktor pemuda sebagai katalisator yang penting di lihat sebagi penggerak BUMDes di desa. Pasalnya, secara konseptual masih sedikit abstraksi kasus yang ada di Indonesia yang menempatkan pemuda sebagai penggerak BUMDes. Alasan lain, alasan praktis dengan melihat kondisi di Indonesia yang dalam beberapa tahun yang akan datang akan menghadapi masa dimana pemuda akan mengalami surplus dalam jumlah yang cukup banyak. Atas alasan itu, maka konseptualisasi yang berupa di tawarkan oleh penelitian ini dapat di lihat dalam skema berikut ini.

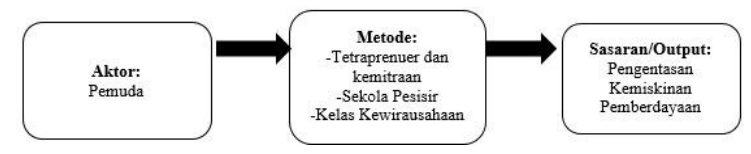

Sumber : Dikembangkan dari berbagai konsep

Bagan 2. Kerangka Konseptual Penelitian

\section{METODE PENELITIAN}

\section{Jenis Penelitian}

Penelitian di lakukan di desa Pitue Kecamatan Ma'rang Kabupaten Pangkajene dan Kepulauan. Mengambil fokus pada peran dan keterlibatan pemuda dalam mengembangkan BUMDes (Badan Usaha Milik Desa).

\section{Teknik Pengumpulan Data}

Penelitian menggambil metode deskriptif kualitatif, dengan wawancara dan observasi langsung sebagai Teknik pengumpulan data. Selama pengumpulan data, peneliti terjun dan terlibat langsung pada kegiatan-kegiatan $B U M D e s$ di desa Pitue, salah satunya sekolah Pesisir. Keterlibatan peneliti pada kegiatan yang dilakukan oleh BUMDes desa Pitue ikut memberikan kesan yang mendalam terhadap data dan informasi yang di peroleh seolah tidak berjarak dengan peneliti. Tetapi bukan berarti bahwa data yang di tampilkan sangat subyektif dari sudut pandang penulis. Untuk memberikan perbandingan terhadap data lapangan, peneliti juga mengambil data-data sekunder. Tujuannya untuk memperkuat hasil wawancara dan temuan lapangan penelitian. Beberapa data sekunder yang digunakan pada penelitian ini, diantaranya dokumen dan laporan rutin BUMDes, laporan yang dirilis secara resmi oleh instansi seperti laporan rutin BPS.

Selama melangsungkan penelitian dan wawancara langsung, peneliti juga 
sempat mengunjungi langsung BUMDes yang menjadi pusat kegiatan masyarakat desa. Di BUMDes tersebut, peneliti berkesempatan melihat secara langsung proses yang berlangsung di BUMDes. Selain itu, peneliti juga berkesempatan memewawancarai direktur BUMDes di desa Pitue yang sekaligus sebagai tokoh pemuda yang menjadi penggerak $B U M D e s$, Ibu-ibu penggiat pada kegiatan pemberdayaan di desa Pitue serta beberapa oknum aparat pemerintah serta tokoh masyarakat yang ikut terlibat pada kegiatan pemberdeyaan di BUMDes desa Pitue.

\section{Analisis Data}

Analisis data digunakan dengan mendeskripsikan temuan lapangan, yang kemudian di komperasikan dengan beberapa studi terdahulu mengenai tata kelola Bumdes. Penelitian ini menggunakan model pembahasan induktif, dengan menggali abstraksi model pengelolaan Bumdes yang ada di Desa Pitue kemudian di kembangkan dengan membandingkan dengan model-model tata kelola di tempat lain.

\section{HASIL DAN PEMBAHASAN}

\section{Peran Pemuda dalam Mengembangkan BUMDes}

Keberadaan pemuda dalam mengelola BUMDes mampu mendorong partisipasi masyarakat dan memberdayakan masyarakat melalui kegiatan kelompok binaan BUMDes Mattuju. Pertama, mendorong partisipasi masyarakat dalam pelaksanaan program BUMDes. Dalam hal ini partisipasi secara langsung masyarakat desa untuk mengambil bagian dalam kegiatan yang dilakukan oleh $B U M D e s$ berbasis potensi lokal didorong oleh pemuda. Mayarakat desa yang didorong untuk terlibat secara langsung perlu diimbangi dengan kualitas dan kemampuan sumber daya manusia

dalam pelaksanaan program kegiatan BUMDes. Sehingga, awalnya diberikan kegiatan agar masyarakat memperoleh peningkatan kualitas sumber daya manusia melalui Sikolahh Pesisir.
Sikolah Pesisir

Salah satu bentuk kegiatan untuk meningkatkan kapasitas masyarakat desa yaitu dengan hadirnya Sikolahh Pesisir. Kegiatan tersebut adalah inisiasi dari salah satu pemuda desa dengan mendorong masyarakat desa yaitu ibu-ibu rumah tangga agar keluar dari buta aksara dan mempunyai kemampuan untuk nantinya dapat mengambil bagian dalam kegiatan yang akan dilakukan oleh BUMDes.

"Saya memberdayakan masyarakat kelompok perempuan seperti ibu-ibu rumah tangga yang tidak mempunyai pekerjaan untuk terlibat dalam kegiatan ekonomi yang ada didesa. Karena sulitnya lapangan pekerjaan sedangkan potensi desa banyak. Mereka tidak mempunyai skill untuk mengolahnya. Jadi, bagaimana saya mendorong mereka dan mengajari mereka cara membuka wirausaha didesa. Awalnya dulu mereka dibukakan sekolah pesisir. Bagaimana mengeluarkan mereka dari buta aksara yang dulunya tidak tahu membaca, menulis, dan menghitung maka mereka dibukakan sekolah pesisir. Sekolah pesisir dulu yang kita ajarakan, pribadi mereka dulu yang diajarkan bagaimana meningkatkan kapasitas mereka."

Sikolahh pesisir mendorong perempuan produktif untuk ikut serta dalam kegiatan sekolah pesisir, untuk mengeluarkan mereka dari buta aksara.

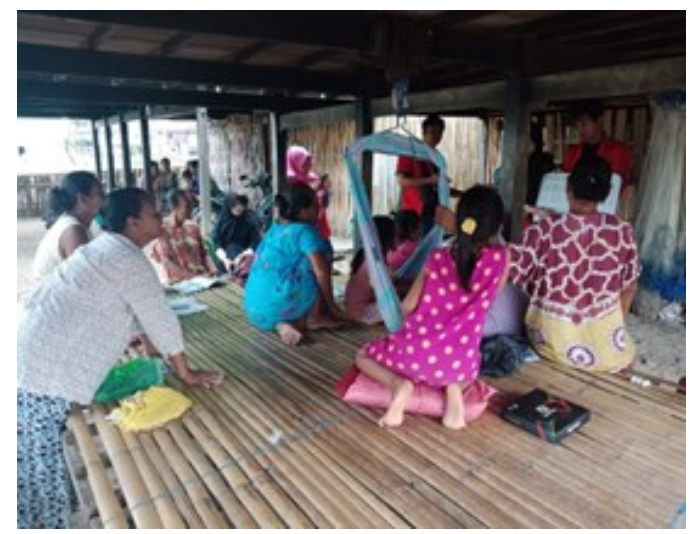

Sumber: $\quad B U M D e s \quad$ Mattuju.Data sekunder,diolah

Gambar. 1 Sikolah pesisir

Dari hasil penelitian, peran pemuda dengan wujud diatas disebut juga peran 
pemuda sebagai katalisator yaitu model peran pemuda yang mengadakan perubahan- perubahan dalam masyarakat ke arah yang lebih baik. Perdianto menemukan bahwa peran pemuda dalam mengembangkan pedesaan, dimana bentuk peran pemuda yang dimaksud adalah keikutsertaan pemuda secara penuh dalam mendesain pembangunan pedesaan (Perdianto et al., 2020). Bentuk peran pemuda dapat dilihat dari kepeduilan pemuda terhadap masyarakat desa melalui dorongan pemuda agar masyarakat desa tersebut memiliki peningkatan kapasitas untuk nantinya berpartisipasi dalam kegiatan kelompok usaha binaan $B U M D e s$ Mattuju.

"Keinginan untuk memajukan desa muncul dari dalam. Saya berfikir bahwa saya ini anak muda harus punya kontribusi terhadap desa. Persoalan keterampilan pribadi semua orang punya bakat. Pengetahuan dan keterampilan diperoleh melalui proses. Kalau dari gagasan itu timbul dari dalam juga. Saya ingin melihat bahwa saya ini anak muda, saya harus mempunyai kegiatan ekonomi. Saya ikut andil dalam bagaimana membangun desa. Memberikan bukti bahwa ternyata hidup di desa jauh lebih bagus dari pada di kota. Kemudian membuka usaha kembali ke desa itu jauh lebih bagus dari pada tinggal di kota. Maka, sekolah pesisir dulu yang kita ajarkan. Kemudian, disitulah mengajak mereka untuk terlibat. Tanggapannya masyarakat senang setelah itu, termotivasi mereka dibukakan kelas kewirausahaan untuk pengembangan ekonomi masyarakat desa. Mereka didorong untuk jadi wirausaha karena potensi banyak, bahan baku melimpah. Jadi, mereka tidak pusing mengolahnya. Dulu mereka tidak ada keinginan untuk mau berwirausaha. Dengan hadirnya BUMDes dengan ide untuk melakukan kegiatan ekonomi desa dan membuat project-project supaya mereka mulai tertarik sehingga mereka ingin terlibat juga dalam kegiatan ini.",2

Keberadaan pemuda yang memiliki peran dalam pengelolaan BUMDes Mattuju ini yaitu mampu mendorong masyarakat desa untuk berpartisipasi dan meningkatkan kapasitasnya untuk nantinya mau diajak terlibat dalam kegiatan yang akan dilakukan oleh BUMDes Mattuju berbasis pengembangan potensi desa yang akan menunjang kemandirian desa.

\section{Pemberdayaan Masyarakat Desa}

Setelah masyarakat didorong oleh pemuda untuk berpartisipasi dalam program kegiatan $B U M D e s$ Mattuju yang diawali dengan kegiatan peningkatan kapasitas pribadi masyarakat desa. Kemudian, pemuda melakukan pemberian pelatihan keterampilan kepada masyarakat yang ikut berpartisipasi dalam program kegiatan BUMDes Mattuju melalui pembuatan kelompok-kelompok usaha binaan untuk meningkatkan pengetahuan dan keterampilan.

Masyarakat yang diberdayakan oleh pemuda yang mengelola $B U M D e s$ Mattuju ini adalah kelompok masyarakat Desa Pitue yaitu ibu-ibu rumah tangga. Bentuk kegiatan pemberdayaan masyarakat yang dilakukan pemuda yang berperan sebagai direktur BUMDes yaitu memberikan kelas kewirausahaan bagi kelompok masyarakat yaitu ibu-ibu rumah tangga yang ikut berpartisipasi dalam kelompok usaha binaan BUMDes Mattuju melalui pelaksanaan kegiatan produktif yang akan nantinya menghasilkan sebuah produk hasil pengolahan bahan mentah berbasis potensi Desa Pitue.

"Kita diundang rapat di Kantor Desa. Nah, disitu kita disuruh buat kelompok. Ditanya maki' bilang mauki? Pada waktu itu banyak kelompok usaha yang mau dia buat. Ada pembuatan keripik, abon, terasi, minyak kelapa, minyak kelapa murni VCO. Disitu kita pilih. Kemudian baru dikasih maki pelatihan.",

Wujud peran dalam kegiatan pemberdayaan yaitu kelompok usaha binaan BUMDes Mattuju di Desa Pitue. Kegiatan pemberdayaan ini memberikan ruang kepada masyarakat Desa Pitue yaitu ibu-ibu perempuan untuk mengembangkan potensi yang ada di Desa Pitue. Dengan 
mengikutsertakan dalam kegiatan kelompok usaha binaan BUMDes Mattuju.

\section{Kelas Kewirausahaan}

Pasca mengikuti sekolah pesisir kemudian membuka kelas kewirausahaan kepada masyarat dengan memanfaatkan potensi Desa Pitue. Adapun kegiatan pemberdayaan berupa pelatihan dalam bentuk kelas kewirausahaan yang diberikan yaitu pelatihan pembuatan kerupuk, abon, terasi, minyak kelapa kemasan, minyak kelapa murni, dan mie yang merupakan kegiatan berbasis pemberdayaan masyarakat Desa.

"Disini para ibu-ibu rumah tangga yang diberdayakan. Modalnya itu dari kelompokji sendiri artinya modal sendiri. BUMDes itu maujaki nakasih modal tapi boleh dikata kita terlalu terikat kalau begitu. Kalau lancarji omset pesanannya tidak ada masalah. Tapi, siapa tau kita sudah ambil disitu di BUMDes ternyata kandas dia punya pesanan kita nanti yang setengah mati bayar itu. Namanya saja utang harus dibayar pasti. Jadi, modal sendiri itu semua kelompok disini. Tidak ada bantuan dari desa, kecuali pernah ada bantuan tapi berupa alat. Kalau berupa modal uang itu tidak ada. Kalau sekarang yang aktif 10 orang, saya disini pembina kelompok. Disini usahanya pembuatan keripik udang dan ikan bandeng. Hasil produksinya itu diambil oleh BUMDes dia yang beli. Artinya, dia kasih memang harga dikita sekian. Kemudian, dikemas disana. Produksi saja disini. Pengemasan dan pemasaran itu BUMDes. Artinya, kalau kita disini boleh dikata dapat tonji untung, bergabungji anggotanya, silaturahmi semakin dekat ituji tidak renggang hubungan apalagi disini kan berjauhan rumah jauh-jauh semua." 4

BUMDes Mattuju mewadahi kelompok usaha yang ada di Desa Ptue. Dalam hal ini BUMDes tidak hanya sekedar wadah yang membantu dalam memberikan pelatihan tetapi juga membantu dalam hal seperti bantuan pengemasan maupun pemasaran bagi para masyarakat yang berpartisipasi dalam kelompok usaha binaan BUMDes yang dananya ditanggung secara bersama-sama oleh masing-masing kelompok usaha binaan.

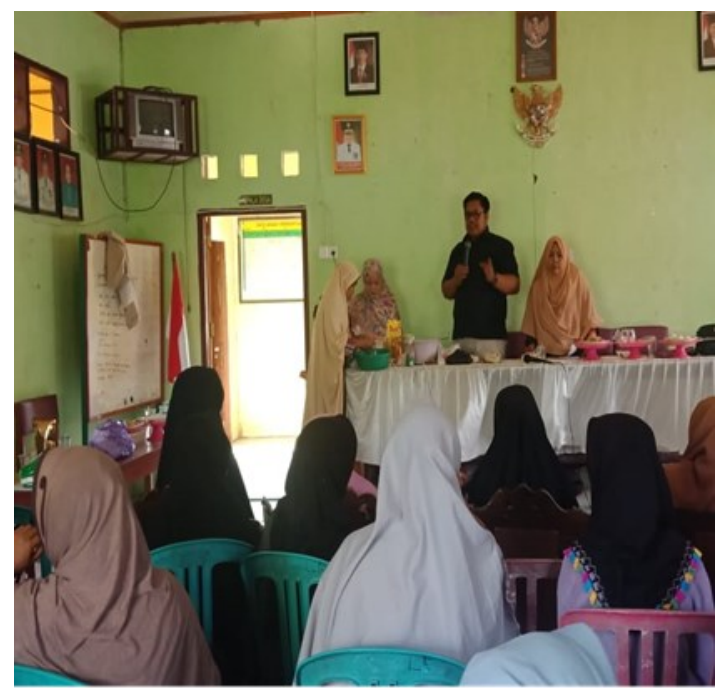

Sumber: Dokumentasi Pribadi, 2019

\section{Gambar 2. Kelas Kewirausahaan}

Dengan adanya partisipasi dari masyarakat yang diimbangi dengan kapasitas dan keterampilan sumber daya manusia yang menghasilkan produk hasil pengolahan potensi desa berbasis pemberdayaan masyarakat desa, sehingga menciptakan sumber daya ekonomi masyarakat desa pitue yang ikut berpartisipasi dalam kelompok usaha binaan BUMDes Mattuju. Serta program $B U M D e s$ mendapat banyak aspirasi dan akan dirasakan oleh seluruh lapisan masyarakat.

\section{Produk BUMDes}

BUMDes Mattuju yang dikelolah langsung oleh pemuda itu mewadahi semua kelompok usaha atau industri kecil yang ada di desa. Kelompok unit usaha yang dikelola oleh BUMDes Mattuju yaitu Cahaya Desa, Mutiara Desa, Soreang Bersinar, Massingereng, Resky, Cahaya Mentari, Maju Bersama, Pesisir Jaya. BUMDes Mattuju menghimpun unit-unit usaha melalui partisipasi dan pemberdayaan masyarakat dengan mengembangkan potensi lokal yang ada di 
Desa Pitue sehingga menciptakan sumber daya ekonomi masyarakat desa pitue yang ikut berpartisipasi dalam kelompok usaha binaan BUMDes Mattuju.

\begin{tabular}{|c|c|c|c|c|c|}
\hline No. & $\begin{array}{l}\text { Kelompok } \\
\text { Usaha } \\
\text { Binaan } \\
\text { BUMDes } \\
\text { Mattuju }\end{array}$ & $\begin{array}{l}\text { Mayara } \\
\text { kat } \\
\text { yang } \\
\text { diberda } \\
\text { yakan }\end{array}$ & $\begin{array}{l}\text { Potensi Desa } \\
\text { yang } \\
\text { dikembangkan }\end{array}$ & $\begin{array}{l}\text { Program } \\
\text { Pemberdayaa } \\
\text { n }\end{array}$ & $\begin{array}{l}\text { Hasil } \\
\text { Produksi } \\
\text { Pengolahan } \\
\text { Potensi Desa } \\
\text { Berbasis } \\
\text { Pemberdayaa } \\
\text { n Masyarakat } \\
\end{array}$ \\
\hline 1. & $\begin{array}{l}\text { Sumber: } \\
\text { Dokumentasi } \\
\text { 19/03/2019 }\end{array}$ & $\begin{array}{l}\text { Ibu-ibu } \\
\text { Rumah } \\
\text { Tangga }\end{array}$ & $\begin{array}{l}\text { Ikan Bandeng dan } \\
\text { Kepiting }\end{array}$ & $\begin{array}{l}\text { Pelatihan } \\
\text { produksi } \\
\text { pengolahan } \\
\text { Ikan Bandeng } \\
\text { dan Kepiting } \\
\text { yaitu Pelatihan } \\
\text { Pembuatan } \\
\text { Kerupuk }\end{array}$ & $\begin{array}{l}\text {-Puang Crab } \\
\text {-Kacang } \\
\text { Bandeng Kriuk } \\
\text {-Arung Bolu } \\
\text { (Kerupuk } \\
\text { Keriting } \\
\text { Bandeng) }\end{array}$ \\
\hline 2. & $\begin{array}{l}\text { Sumber: } \\
\text { Dokumentasi } \\
\text { 20/03/2019 } \\
\end{array}$ & $\begin{array}{l}\text { Ibu-ibu } \\
\text { Rumah } \\
\text { Tangga }\end{array}$ & Kelapa & $\begin{array}{l}\text { Pelatihan } \\
\text { produksi } \\
\text { pengolahan } \\
\text { Kelapa yaitu } \\
\text { Pelatihan } \\
\text { Pembuatan } \\
\text { Minyak } \\
\text { Kemasan }\end{array}$ & $\begin{array}{l}\text { Minyak Kelapa } \\
\text { Kemasan }\end{array}$ \\
\hline 3. & $\begin{array}{l}\text { Mutiara Desa } \\
\text { Sumber: } \\
\text { Dokumentasi } \\
\text { 18/03/2019 }\end{array}$ & $\begin{array}{l}\text { Ibu-ibu } \\
\text { Rumah } \\
\text { Tangga }\end{array}$ & $\begin{array}{l}\text { Ikan Bandeng dan } \\
\text { Udang }\end{array}$ & $\begin{array}{l}\text { Pelatihan } \\
\text { produksi } \\
\text { pengolahan } \\
\text { Ikan Bandeng } \\
\text { dan Udang } \\
\text { Vannamei } \\
\text { yaitu Pelatihan } \\
\text { Pembuatan } \\
\text { Kerupuk }\end{array}$ & $\begin{array}{l}\text {-Snack Nona } \\
\text { Bandeng } \\
\text {-Snack Doang } \\
\text { Pute (Udang } \\
\text { Vannamei ) }\end{array}$ \\
\hline
\end{tabular}




\begin{tabular}{|c|c|c|c|c|c|}
\hline 4. & $\begin{array}{l}\text { Cahaya } \\
\text { Mentari } \\
\text { Sumber: } \\
\text { Dokumentasi } \\
\text { 18/03/2019 }\end{array}$ & $\begin{array}{l}\text { Ibu-ibu } \\
\text { Rumah } \\
\text { Tangga }\end{array}$ & Terasi Bubuk & $\begin{array}{l}\text { Pelatihan } \\
\text { produksi } \\
\text { pengolahan } \\
\text { Udang yaitu } \\
\text { Pelatihan } \\
\text { Pembuatan } \\
\text { Terasi Bubuk }\end{array}$ & Terasi Bubuk \\
\hline 5. & $\begin{array}{l}\text { Sumber: } \\
\text { Dokumentasi } \\
\text { 19/03/2019 }\end{array}$ & $\begin{array}{l}\text { Ibu-ibu } \\
\text { Rumah } \\
\text { Tangga }\end{array}$ & Kelapa & $\begin{array}{l}\text { Pelatihan } \\
\text { produksi } \\
\text { pengolahan } \\
\text { Kelapa yaitu } \\
\text { Pelatihan } \\
\text { Pembuatan } \\
\text { Minyak } \\
\text { Murni VCO }\end{array}$ & $\begin{array}{l}\text { Minyak } \\
\text { Murni VCO }\end{array}$ \\
\hline 6. & $\begin{array}{l}\text { Maju } \\
\text { Bersama } \\
\text { Sumber: } \\
\text { Dokumentasi } \\
\text { 19/03/2019 }\end{array}$ & $\begin{array}{l}\text { Ibu-ibu } \\
\text { Rumah } \\
\text { Tangga }\end{array}$ & Kelapa & $\begin{array}{l}\text { Pelatihan } \\
\text { produksi } \\
\text { pengolahan } \\
\text { Kelapa yaitu } \\
\text { Pelatihan } \\
\text { Pembuatan } \\
\text { Minyak } \\
\text { Murni VCO }\end{array}$ & $\begin{array}{l}\text { Minyak } \\
\text { Murni VCO }\end{array}$ \\
\hline 7. & $\begin{array}{l}\text { Massengeren } \\
\mathrm{g}\end{array}$ & $\begin{array}{l}\text { Ibu-ibu } \\
\text { Rumah } \\
\text { Tangga }\end{array}$ & $\begin{array}{l}\text { Ikan Bandeng } \\
\text { dan Kepiting }\end{array}$ & $\begin{array}{l}\text { Pelatihan } \\
\text { produksi } \\
\text { pengolahan } \\
\text { Ikan Bandeng } \\
\text { dan Kepiting } \\
\text { yaitu } \\
\text { Pelatihan } \\
\text { Pembuatan } \\
\text { Abon }\end{array}$ & $\begin{array}{l}\text {-Abon } \\
\text { Bandeng } \\
\text {-Abon } \\
\text { Kepiting }\end{array}$ \\
\hline
\end{tabular}




\begin{tabular}{|c|c|c|c|c|c|}
\hline 8. & $\begin{array}{l}\text { Resky } \\
\text { Sumber: } \\
\text { Dokumentasi } \\
\text { 19/03/2019 }\end{array}$ & $\begin{array}{l}\text { Ibu-ibu } \\
\text { Rumah } \\
\text { Tangga }\end{array}$ & Rumput Laut & $\begin{array}{l}\text { Pelatihan } \\
\text { produksi } \\
\text { pengolahan } \\
\text { rumput laut } \\
\text { yaitu } \\
\text { Pelatihan } \\
\text { Pembuatan } \\
\text { Mie }\end{array}$ & Mie sehat \\
\hline
\end{tabular}

Sumber: diolah dari hasil catatan lapangan, 2019

Keterlibatan pemuda dalam mengembangkan BUMDes di desa Pitue terbukti sangat efektif, yang tidak hanya memajukan BUMDes tetapi pada taraf tertentu mampu mendorong keterlibatan masyarakat dalam kegiatan pemberdayaan. Kesadaran dan kepedulian pemuda kata kunci yang menjadi faktor yang ikut menggerangkan pemuda untuk ikut terlibat dalam mengembangkan $B U M D e s$. Selaras dengan penelitian Haryati,dkk yang menunjukan sikap kepedulian pemuda menjadi hal yang sangat penting. Kepedulian pemuda menjadi pendorong yang ikut menggerakkan pemuda (Haryati et al., 2016)

\section{PENUTUP}

\section{Kesimpulan}

Abstraksi kasus yang berlangsung di desa Pitu di Kabupaten Pangkajene dan Kepulauan dengan melibatkan pemuda sebagai penggerak BUMDes menjadi salah satu abstraksi dari tata kelola BUMDes yang berhasil. Dengan menjadikan pemuda sebagai aktor kunci yang ikut memainkan peran yang sangat startegis. Temuan ini, melengkapi modelmodel tata kelola $B U M D e s$ yang selama ini berlangsung di Indonesia (Abdur Rozaki \& Siti Rohaya, 2019; Alkaff, 2016; Firdaus, 2018; Hayyuna et al., 2014; Perdianto et al., 2020; Rahmatika et al., 2019; Salam, 2018; Sayuti, 2011; Yuni et al., 2013) yang tidak hanya bertumpu pada aparat pemerintah, perempuan tetapi temuan ini menawarkan alternatif dengan menjadikan pemuda sebagai sentral.

Secara praktik, penelitian ini memberikan kebaharuan terutama dalam melihat praktek tata kelola BUMDes di Indonesia. Temuan lapangan menyimpulkan jika keterlibatan pemuda sangat efektif dalam menggerakan BUMDes. Hal ini terlihat dari keberhasilan pemuda memoles BUMDes, sehingga melalui $B U M D e s$ masyarakat dapat menyelenggarakan berbagai kegiatan seperti Sikolah pesisir, pemberdayaan perempuan pesisir dan pelatihan kewirausahaan yang semuanya di selenggarakan oleh BUMDes atas inisiasi pemuda.

Terakhir, temuan penelitian ini juga menjadi antitesa dari beberapa penelitian sebelumnya, terutama bagi kubu yang melihat pesimis tautan kemiskinan, pemberdayaan dan BUMDes (Prasetyo, 2016; Ridlwan, 2015; Sudirno et al., 2020). Artikel ini ingin melengkapi diskusi artikel sebelumnya, dengan mengambil posisi bahwa berdasarkan temuan-temuan lapangan keberadaan BUMDes sangat efektif dalam memerangi masalah kemiskinan yang ada di desa sekaligus mendorong kegiatan pemberdayaan masyarakat. Argumen ini setidaknya memperkuat para peneliti sebelumnya yang melihat tautan $B U M D e s$, kemiskinan dan pemberdayaan dengan kesimpulan yang optimisi (Faedlulloh, 2018; Laru \& Suprojo, 2019; Rahmatika et al., 2019). 


\section{Saran}

Dari temuan diatas, dapat dilihat bahwa keterlibatan pemuda sebagai penggerak pada Bumdes di desa terbukti sangat efektif, terutama untuk menggerakan Bumdes dan mengembangkan pemberdayaan masyarakat desa khususnya di desa Pitue. Berkaitan dengan itu kiranya perlu Pengambil kebijakan perlu mempertimbangkan keterlibatan aktor pemuda sebagai salah satu penggerak Bumdes.

\section{DAFTAR PUSTAKA}

Abdur Rozaki, \& Siti Rohaya. (2019). Memberdayakan Desa Melalui Pariwisata Berbasis Bumdes. Engagement: Jurnal Pengabdian Kepada Masyarakat, 3(1), 1-20. Https://Doi.Org/10.29062/

Engagement.V3i1.46

Alkaff, A. (2016). Revitalisasi Bumdes Dalam Upaya Meningkatkan Kemandirian Dan Penanggulangan Kerentanan Kemiskinan Masyarakat Desa Di Kabupaten Jember. Paradigma Madani, 3(2), 33-44.

Faedlulloh, D. (2018). Bumdes Dan Kepemilikan Warga: Membangun Skema Organisasi Partisipatoris. Journal Of Governance, 3(1), 1-17. Https://Doi.Org/10.31506/ Jog.V3i1.3035

Falikhah, N. (2017). Bonus Demografi Peluang Dan Tantangan Bagi Indonesia. Alhadharah: Jurnal Ilmu Dakwah, 16(32). Https:// Doi.Org/10.18592/

Alhadharah.V16i32.1992

Firdaus, S. (2018). Fenomena Elite Capture Dalam Pengelolaan Badan Usaha Milik Desa (Bumdes): Studi Kasus Strategi Bekerjanya Kekuasaan Elite Dalam Pengelolaan Bumdes Argosari, Desa Pulosari, Kabupaten Pemalang. Politika, 9(2), 20-37. Http://Www.Worldbank.Org/En/ Topic/ Communitydrivendevelopment/ Overview\#1
Haryati, S., Armawi, A., Peran, S., Dalam, P., Kawasan, M., Supraja, M., Ilmu, F., Universitas, P., \& Mada, G. (2016). Masyarakat Desa (Studi Tentang Pemuda Pengelola Desa Wisata Kandri , Kecamatan Gunungpati , Kota Semarang , Provinsi Jawa Tengah) Perjalanan Bangsa Indonesia Tidak Lepas. Jurnal Ketahanan Nasional, 22(2), 117-136. Hasbi, M. Tang, A. H. (2019). Sekuritas Sosial Perempuan Rawan Sosial Ekonomi Pada Komunitas Nelayan Pulau Kecil (Kasus Pulau Salemo, Desa Mattiro Bombang, Kecamatan Liukang, Kabupaten Pangkajene Kepulauan, Sulawesi Selatan).

Hayyuna, R., Pratiwi, R. N., \& Mindarti, L. I. (2014). Strategi Manajemen Aset Bumdes Dalam Rangka Meningkatkan Pendapatan Desa (Studi Pada Bumdes Di Desa Sekapuk Kecamatan Ujungpangkah, Kabupaten Gresik). Jurnal Administrasi Publik, 2(1), 1-5. Http:// Administrasipublik.Studentjournal.U b.Ac.Id/Index.Php/Jap/Article/ View/330

Hermawan, I. (2015). Analisis Eksistensi Sektor Pertanian Terhadap Pengurangan Kemiskinan Di Pedesaan Dan Perkotaan. Mimbar, Jurnal Sosial Dan Pembangunan, 28 (2), 135-144.

Jati, W. R. (2014). Globalisasi Dan Kemiskinan Desa: Analisa Struktur Ekonomi. Jurnal Penelitian Politik, 11 (2), 17-26.

Laru, F. H. U., \& Suprojo, A. (2019). Peran Pemerintah Desa Dalam Pengembangan Badan Usaha Milik Desa (Bumdes). Jisip: Jurnal Ilmu Sosial Dan Ilmu Politik, 5(2), 59-63. Https://Publikasi.Unitri.Ac.Id/ Index.Php/Fisip/Article/View/2017

Maryati, S. (2015). Dinamika Pengangguran Terdidik: Tantangan Menuju Bonus Demografi Di Indonesia. Economica, 3(2), 124-136. Https://Doi.Org/10.22202/ Economica.2015.V3.I2.249

Nasfi. (2020). Pengembangan Ekonomi Pedesaan Dalam Rangka Mengentas 
Kemiskinan Di Pedesaan. Jurnal ElRiyasah, 11(1), 54-66.

Noor, M. (2015). Serat Acitya - Jurnal Ilmiah. Serat Acitya-Jurnal Ilmiah, 4 (1), 121-128.

Noveria, M., \& Malamassam, M. A. (2015). Penciptaan Mata Pencaharian Alternatif: Strategi Pengurangan Kemiskinan Dan Perlindungan Sumber Daya Laut (Studi Kasus Kota Batam Dan Kabupaten Pangkajene Dan Kepulauan). Jurnal Kependudukan Indonesia, 10(2), 139. Https://Doi.Org/10.14203/ Jki.V10i2.73

Perdianto, R., Qadarsih, A. M., Nurma, A. D. E., Putra, J., Nusantara, S., \& Sungai, S. (2020). Peran Aktif Pemuda Era Globalisasi Dalam Pembangunan Desa Muara Semerah Kecamatan Air. 2(8), 23-31.

Prasetyo, R. A. (2016). Peranan Bumdes Dalam Pembangunan Dan Pemberdayaan Masyarakat Di Desa Pejambon Kecamatan Sumberrejo Kabupaten Bojonegoro. Maret, Xi(1), 86.

Rahmatika, D. N., Subroto, S., Indriasih, D., \& Prihadi, D. (2019). Strategi Pengembangan Kualitas Bumdes: Pendekatan Model Tetrapreneur Serta Kemitraan Dengan Perguruan Tinggi Dan Perbankan. Jurnal Industri Kreatif Dan Kewirausahaan, 2(2), 85 $-96$.

Ridlwan, Z. (2015). Urgensi Badan Usaha Milik Desa (Bumdes) Dalam Pembangun Perekonomian Desa. Fiat Justisia:Jurnal Ilmu Hukum, 8(3), 424-440. Https://Doi.Org/10.25041/ Fiatjustisia.V8no3.314

Salam, Anisa Nur. (2018). Pengentasan Kemiskinan Melalui Pengembangan Badan Umum Milik Desa (Bumdes). Az Zarqa', 10(5), 370-396.

Sayuti, H. M. (2011). Pelembagaan Badan Usaha Milik Desa (Bumds) Sebagai Penggerak Potensi Ekonomi Desa Dalam Upaya Pengentasan Kemiskinan Dikabupaten Donggal. Jurnal Academica Fisip Untad, 03 (02), 717-728.

Sudirno, D., Masduki, M., Suparto, L.,
Nahdi, D. S., \& Sumianto, T. (2020). Peningkatan Kapasitas Badan Usaha Milik Desa (Bumdes) Mapan Desa Panjalin Kidul. Bernas: Jurnal Pengabdian Kepada Masyarakat, 1 (1), 53-58. Https://Doi.Org/10.31949/ Jb.V1i1.155

Sumarti, T. (2007). Kemiskinan Petani Dan Strategi Nafkah Ganda Rumahtangga Pedesaan. Sodality: Jurnal Sosiologi Pedesaan, 1(2), 217 -232. Https://Doi.Org/10.22500/ Sodality.V1i2.5930

Suryana, I. M., Setiyono, T. J., \& Murdoyuwono, C. S. (2015). Pemberdayaan Kelompok Tani Melalui Bumdes ( Badan Usaha Milik Desa ). Jurnal Bakti Saraswati, 04 (02), 138-144.

Syam, A. (N.D.). Pemberdayaan Perempuan Dalam Pembuatan Pola Dasar Busana Untuk Meningkatkan Pendapatan Keluarga Di Kabupaten Pangkep. 26-29.

Tohani, E. (2011). Pendidikan Nonformal Dan Pengurangan Kemiskinan Di Pedesaan. Walisongo: Jurnal Penelitian Sosial Keagamaan, 19(2), $385 . \quad$ Https://Doi.Org/10.21580/ Ws.2011.19.2.163

Umar, M. A. (2020). Bonus Demografi Sebagai Peluang Dan Tantangan Di Era Otonomi Daerah. Genta Mulia, 8 (2), 90-99.

Yuni, O. :, Rahma, S., \& Meirinawati, D. (2013). Strategi Pembangunan Desa Dalam Mengentaskan Kemiskinan Desa Melalui Badan Usaha Milik Desa (Bumdes) (Studi Pada Program Usaha Agrobisnis Pertanian (Puap) Di Desa Sareng Kecamatan Geger Kabupaten Madiun).

\section{Catatan Akhir:}

${ }^{1}$ Wawancara dengan Narun/Tokoh Pemuda pada Senin, 18 Maret 2019)

${ }^{2}$ Wawancara dengan Narun/Tokoh Pemuda Senin, 18 Maret 2019)

${ }^{3}$ Wawancara Ibu Halmiah, 38 tahun pada Selasa, 19 Maret 2019)

${ }^{4}$ Wawancara dengan Tokoh Masyarakat/ H. Bahtiar, Umur 49 tahun pada Senin, 18 Maret 2019) 